
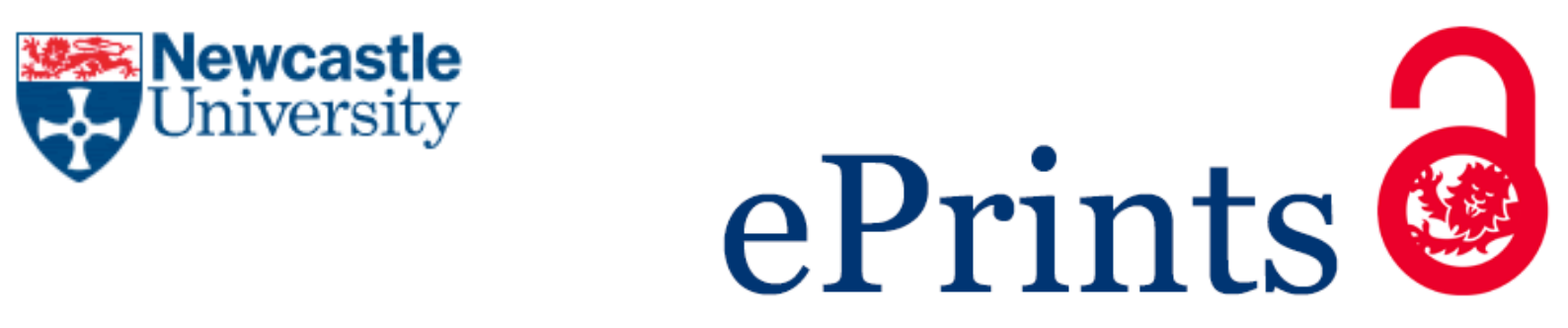

Hogan JV.

Administrators in UK Higher Education: Who, Where, What and How Much? Perspectives: Policy and Practice in Higher Education 2014, 18(3), 76-83.

\title{
Copyright:
}

This is an Accepted Manuscript of an article published by Taylor \& Francis Group in Perspectives: Policy and Practice in Higher Education on 04/07/2014, available online:

http://www.tandfonline.com/10.1080/13603108.2014.930073

Date deposited:

$21 / 07 / 2014$

Embargo release date:

04 January 2016

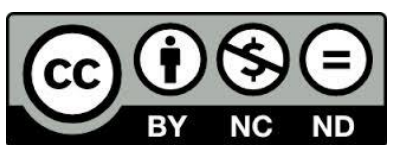

This work is licensed under a

Creative Commons Attribution-NonCommercial-NoDerivs 3.0 Unported License 


\section{Administrators in UK Higher Education: Who, Where, What and How Much?}

Abstract: Just who are 'administrators' in UK higher education? The definition of administrators is explored and it is argued that it has changed to become looser. Administrative roles are now much more diverse. Technological changes have created new roles and opportunities with progression opportunities for some staff. The statistical evidence from the Higher Education Statistics Agency is considered. This shows that a large percentage of support staff work in academic cost centres and changes in the numbers and type of staff working in different areas are considered.

Keywords: administration, higher education, managers, HESA

Who is an administrator?

A review article in Nature written in the first decade of the century opened with the following sentences:

University politics has long been a current phrase, and questions of university government and policy have been increasingly discussed of recent years; yet, in spite of the rapid increase in the number of the English universities, and of the many interesting experiments in organisation which they embody, there has so far been no comprehensive treatise written in this country upon university administration.

An interesting perspective, made remarkable by the fact that it was written in 1909 and not 2009 . The author used the phrase 'university administration' to describe the system of governance. Nowadays the phrase is more likely to be used to describe the management of the university or, more specifically, the staff who work in the central administration. There have also been many publications about and for such staff and others whose role is to help the university function - of which Perspectives itself is a leading example. 'Administration' as a descriptor has become somewhat devalued; the word being used to describe something academic staff may not relish or implying a more routine level of activity. Management is an alternative but one also loaded with meaning, not always positive.

This article will look at some of the statistical information available about administrative staff working in higher education in the UK to help map out some of the key characteristics of these staff. The immediate problem is one of definition; who is a university administrator?

There is no universally accepted definition of administrative staff in universities. Some will accept the label of 'university administrator' with pride, others may use it in a disparaging manner. Is it appropriate to use this label at all? I suggest it is on three grounds. First, it was the description that was widely used when the modern university system was established in the second half of the twentieth century. Second, despite the reservations noted above, it is still widely used. It is worth noting that there is an Association of Heads of University Administration (AHUA) and, of course, the Association of University Administrators (AUA). Thirdly, the alternatives also lack a universally accepted definition. Managers might be accurate in some cases but has connotations. The other important descriptor is 'professional services' or similar (Lauwerys 2002). The HEFCE uses the phrase 'professional and support staff' (HEFCE 2012). While this works as a collective description it is, I suggest, unlikely to be adopted by the individual when asked the question 'what do you do?' The answer 'I am a member of the professional and support staff at the University of $X$ ' lacks a certain snappiness.

\section{Changes since the 1960s}


There can be no doubt that, regardless of the merits of the label, the assumptions about 'administrators' have changed almost beyond recognition. In the 1960s, the era of the Robbins Report and expansion of higher education, the assumption was that administrative staff were akin to an 'internal civil service' (Lockwood p. 81), albeit on a tiny scale. The first Meeting of University Academic Administrators (MUAAS) in 1961 was the foundation to today's AUA. In 1972, a working party on its future noted:

The period since 1945, and more particularly since the mid-1950s, has seen university administration developing along professional lines....universities have rapidly evolved a corps of full-time administrators, themselves largely products of the university system, to assist them in discharging their functions. The number and calibre of the staff taken on by the universities for this purpose, and the increasing complexity and responsibility of their work, has inevitably meant that the career administrator has now become an accepted fact of university life.... The profession is still new and still seeking a positive sense of identity but its existence is an established fact -....(Jones p.54)

Membership of the professional association of administrators was open to full-time staff 'equivalent in status to Assistant Lectures and above' - for status read pay. Administrators were particularly associated with 'academic' administration: registry, faculties, committee servicing were common terms.

In the early 1970s, one authority could note:

...the administrative staff in university offices consists almost entirely of men and women making a career in that field. Many enter it soon after graduation, with short experience which may have little relevance... Whatever their previous activity they nearly all propose to remain in university office work until they retire. (Angus p. 19)

So full-time, graduate, generalists, making a career in administration were the assumptions about university administrators. Not universally male but predominantly so.

Over the decades, these assumptions have been shattered. The scale, culture and functions of higher education have altered dramatically so, of course, have the definition and role of support staff. Changes in technology, delivery and complexity have enabled or required radically different administrative support arrangements. Four developments in particular need to be noted.

The first is the massive growth in the size and functions of administrations to a point where it is appropriate to speak of professional services in the plural rather than the university administration in the singular. Universities typically employ large numbers of well qualified staff with professional qualifications. There may be a dividing line to be drawn between those professional services where the managerial staff are expected to hold a professional qualification - estates, finance, IT, library, and HR for example - and those providing more general support.

Second, within individual services the dividing line between 'administrative' and 'clerical' staff has been blurred. Part of this stems from changes to national pay arrangements with the establishment of a single pay spine from 2006. There is no longer an 'academic equivalent' pay range and separate pay scales for clerical staff (although terms and conditions still vary). A progression route is more open. But more importantly the nature of what an 'administrator' can or should do and what a clerical member of staff can and should do is far more flexible. There is far less emphasis on the production of an immaculate set of minutes, or finely honed letters, or internal memoranda, written 
in long hand by the administrator and typed by the secretary. We all send emails now. Technology has increased productivity and democratised the workplace.

Thirdly, many academic staff hold positions of administrative responsibility. They will have entered higher education to teach and research but at some points in their careers they may, and probably will, accumulate administrative tasks and responsibilities. Many go on to be full-time heads or deans or pro-vice-chancellors. In many respects their day-to-day experiences and skill sets will be similar to administrators but they continue to define themselves with an academic label. It has been argued that the growth in academic staff becoming managers means there is no managerial 'class' or distinctive group in universities (Deem and Brehony). I think this goes too far. It is worth noting that of the 185,585 academic staff in $2012 / 13$, only 500 , or $0.27 \%$, were defined as managers, directors and senior officials in the Higher Education Statistics Agency records. Academic staff have always held senior administrative positions in UK universities. It is certainly the case that more now undertake such administrative roles on a full-time basis but compared to the growth of university administrations this does not appear to be to the exclusion of opportunities for administrative staff.

Fourthly, even within the heartland of 'generalist' or 'academic' administration, there is more specialisation. A local example may help to illustrate this. Many universities used to produce a hard copy calendar that, amongst other things, listed staff on lecturer or equivalent grades. The last edition in Newcastle was 1999/2000. Under the heading for the Student Progress Office it listed ten administrative staff; one Senior Assistant Registrar, two Assistant Registrars, seven Administrative Assistants and one Examinations Officer. In 2014, Newcastle still has a Student Progress Office, although the remit has changed somewhat. The relevant web sites lists about twelve staff on similar grades to those listed in 1999, although it is difficult to make an exact comparison because of the changes to the national pay scales. The titles have changed enormously and include Interaction Team Manager, Graduate School Administrator, Timetabling Manager, Student Case Officer and Administrator (Student Data). Job titles are used to describe the particular function not as a general description of level.

The trend for greater diversification in administrative roles was noted in the Dearing report (1997):

Our survey of administrative and support staff showed that they shared the perception of the personnel professionals that traditional definitions of roles are breaking down, and they are being involved in a wider range of functions than in the past. (p.219)

In an important article in 1999 two eminent registrars noted 'university administration is not a unified profession....university administration is sometimes referred to as a collection of specialisms...' (Allen and Newcomb p.39).

There has been some excellent work on the changes to the nature of administrators especially Celia Whitchurch's identification of 'third space professionals' - staff who have a hybrid role between administrative and academic (Whitchurch 2013). Diversity in roles is a key characteristic now. There is even less expectation of a career for life (Whitchurch 2009).

So a single definition of a 'university administrator' will not work since the roles and labels have become so diverse. Any description has to be looser and broader, incorporating a vast range of technical, highly specialised, as well as general support roles. The AUA now is a broad church which describes itself as 'the professional association for higher education administration and management staff' (AUA website) but it is certainly not the only one. By 1999, the AUA directory listed 30 other organisations representing various specialisms in higher education administration (Allen and Newcomb). There are professional associations for a large number of specialist services in 
higher education including managers of residential accommodation, security officers, purchasing officers, internal auditors and lawyers.

Despite this diversity, there are a number of features that appear reasonably common for administrators. First, employment by an $\mathrm{HEl}$ or within the HE system. This is obvious but it is worth noting that outsourcing of services remains the exception in the UK. Second, a recognition that such employment offers opportunities for development and progression within the higher education system. This may no longer be a job for life but it does imply that a 'career', or at least a significant part of a career, could be spent in this sector. Third, responsibility for activity or activities, beyond teaching and research, which are deemed to be necessary or desirable for the university to operate.

\section{$\underline{\text { Statistical information }}$}

The Higher Education Statistics Agency (HESA) is the body responsible for the collection of annual statistics on higher education institutions in the UK. It publishes in electronic form 'Staff at Higher Education Institutions in the United Kingdom' by academic year with the most recent set for 2012/13 produced in February 2014. This is the most important and comprehensive set of information on staff available. (All figures in this article will be taken from HESA supplied statistics unless otherwise noted (HESA 2014). I am grateful to the staff in the Planning Office at Newcastle University for their assistance with these figures.)

Like all data sets, there needs to be a note of caution. The data are only for 'publicly funded' HEls and the University of Buckingham. It, therefore, excludes the host of private providers that are emerging in England following the changes to the fee arrangements introduced in 2012. These changes are so fundamental that they must, in time, call into question the definition of 'publicly funded'. The data are compiled from individual returns made by all HEls. Although there are guidelines on how returns must be made there will inevitably be some differences in interpretation between institutions and some errors will also be made. All the numbers are rounded to the nearest 5. Nevertheless, this is an excellent source and worthy of careful attention.

In 2012/13, there were 382,515 staff employed in the HE sector, $48.5 \%$ of whom were on academic contracts. (This excludes 110,570 'atypical' staff. These are typically staff on a non-standard flexible contract, sometimes very short-term, and covers a host of complex arrangements mainly with academic commitments. There are 36,495 individuals on non-academic, atypical contracts. This includes examination invigilators and students employed on very short term arrangements. Reporting of atypical staff was changed for 2012/13 with institutions only obliged to return atypical staff on academic contracts (HESA website). So, most staff employed in HEls (196,930 in 2012/13) are, to use the HESA definition, on 'non-academic contracts' or, to be more positive about it, 'support'. This includes 'managers, non-academic professionals, student welfare workers, secretaries, caretakers and cleaners'.

From 2012/13, HESA used a nine set classification of staff on 'non-academic' contracts:

1. Managers, directors and senior officials

2. Professional occupations

3. Associate professional and technical occupations

4. Administrative and secretarial occupations

5. Skilled trades occupations

6. Caring, leisure and other service occupations

7. Sales and customer service occupations

8. Process, plant and machine operatives

9. Elementary occupations 
Most are reasonably clear. HESA's classification 1, managers, directors and senior officials, describes itself. Classification 2, Professional occupations, assumes a degree or equivalent is necessary for the role. Classification 3, Associate professional and technical occupations, assumes a high level vocational qualification. Elementary occupations include cleaners and other manual groups.

HESA further describes groups 1 to 3 as managerial, professional and technical staff, 4 as clerical staff and 5 to 9 as manual. There is no single category of 'administrative' staff. It is, therefore, not surprising that the term 'non-academic' is used by HESA and others as a short-hand, although defining something by what it is not is not a positive recognition.

Classifications 1 to 4 would seem to be the most appropriate to include for an analysis of 'administrative staff' but it certainly includes groups that would not define themselves as administrative - librarians, IT professionals, careers officers, welfare staff, technology transfer managers, estate managers to name but a few. Nevertheless, it is worth looking at classifications 1 to 4 in more detail (Table 1).

Table 1: Number of 'administrative' staff in UK HEls 2012/13

\begin{tabular}{|l|r|r|r|}
\hline Job classification & $\begin{array}{r}\text { Number of } \\
\text { full-time }\end{array}$ & $\begin{array}{r}\text { Number of } \\
\text { part-time }\end{array}$ & Totals \\
\hline Managers, directors and senior officials & 9,750 & 1,300 & 11,050 \\
\hline Professional occupations & 27,695 & 7,985 & 35,680 \\
\hline Associate professional and technical occupations & 33,365 & 10,040 & 43,405 \\
\hline Administrative and secretarial occupations & 40,880 & 23,805 & 64,685 \\
\hline Totals & 111,690 & 43,130 & 154,820 \\
\hline
\end{tabular}

So under this definition of 'administrative' staff in this category form $40.5 \%$ of the HE workforce, a huge proportion. It is worth noting that staff who are managers, directors and senior officials are far less likely to be working part-time (11.8\%) than staff in other administrative classifications (29.1\%).

Probably the most striking set of differences between administrative staff and academic staff is in the gender balances. In managerial, professional and technical staff, women make up 54.2\%, although amongst part-time staff this rises to $77 \%$. For clerical staff $81.9 \%$ are women. Amongst all academic staff $55 \%$ are men rising to $78 \%$ of professors.

Overwhelmingly, administrative staff are on open-ended contracts ( 83 or $84 \%$ ) whereas just over two-thirds of academic staff are in this position (64.4\%). This will reflect, in part, the nature of research work with staff employed on specific projects.

Between 9 and $10 \%$ of administrative staff are from a minority ethnic group, just under the percentage for academic staff (11.8\%). Between 4 and $5 \%$ of administrative staff declare a disability compared to $3.5 \%$ of academic staff.

So how much are administrative staff paid? Here the issue of part-time can distort the figures since the percentage of time employed, and, therefore, any pro-rata salary calculation, is not given. So we must work on full-time pay only (Figures 1-4).

Figure 1: Salary range for full-time managers, directors and senior officials 2012/13 


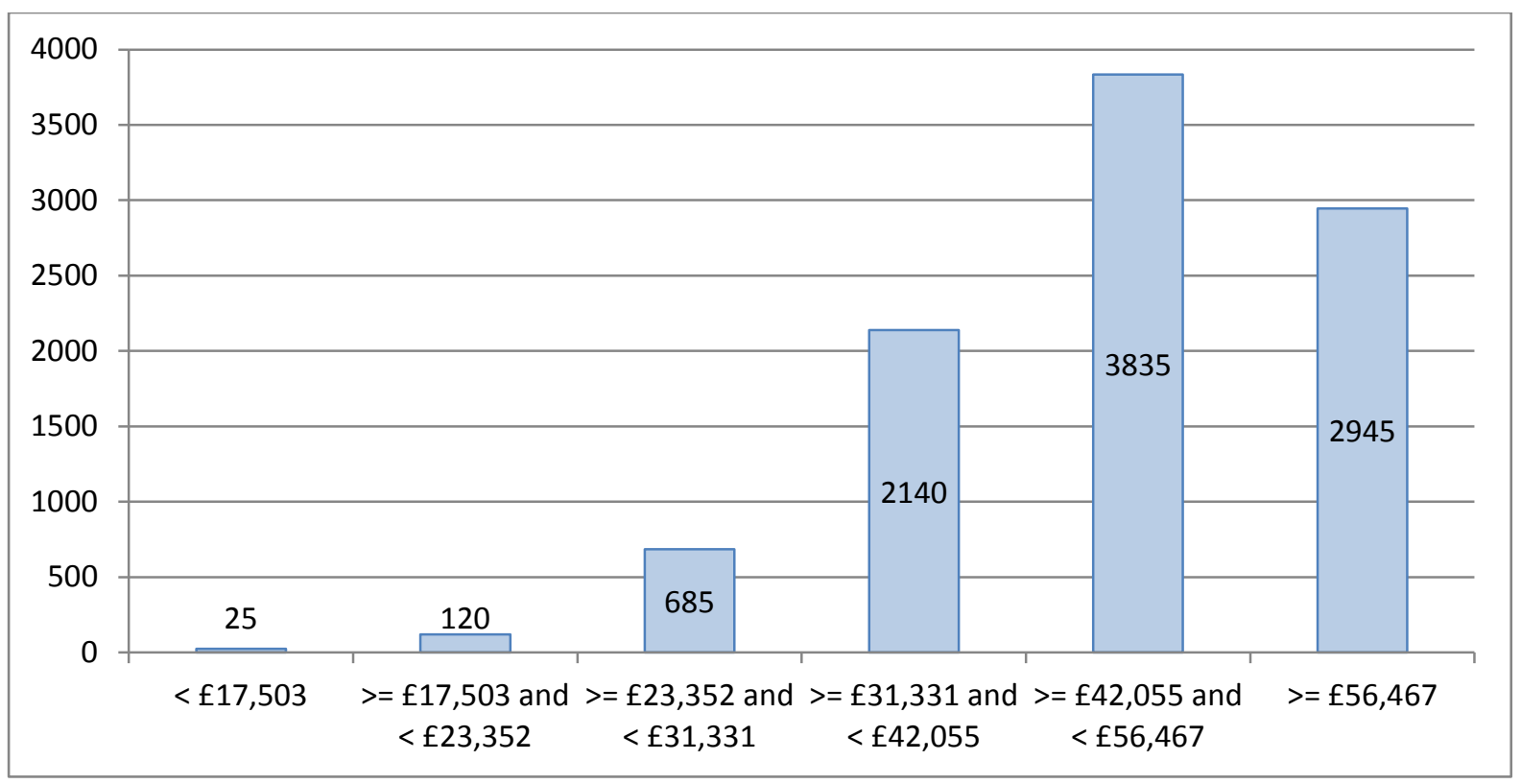

Figure 2: Salary range for full-time professional occupations 2012/13

Figure 3: Salary range for full-time associate professional and technical occupations 2012/13

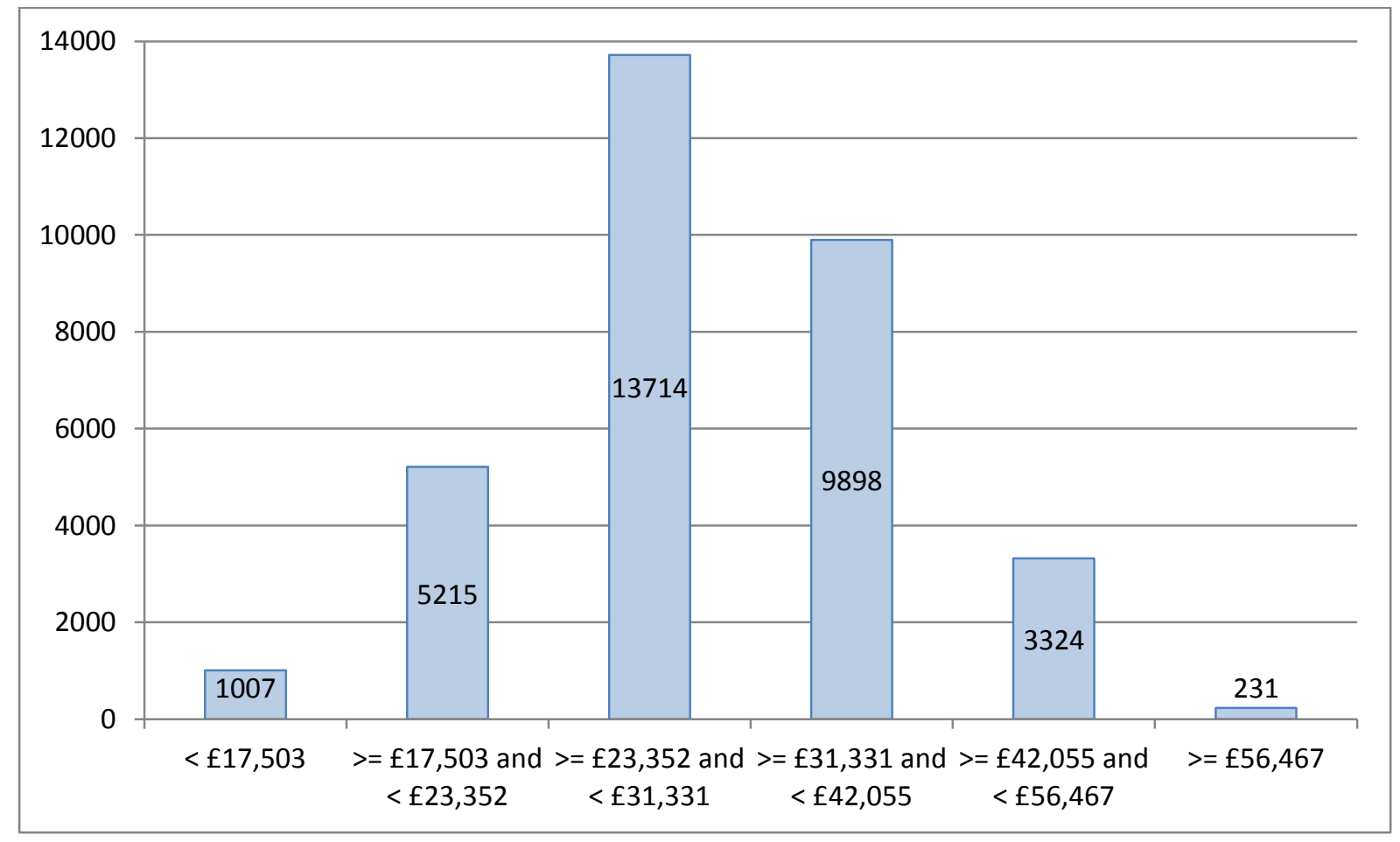

Figure 4: Salary range for full-time administrative and secretarial occupations 2012/13 


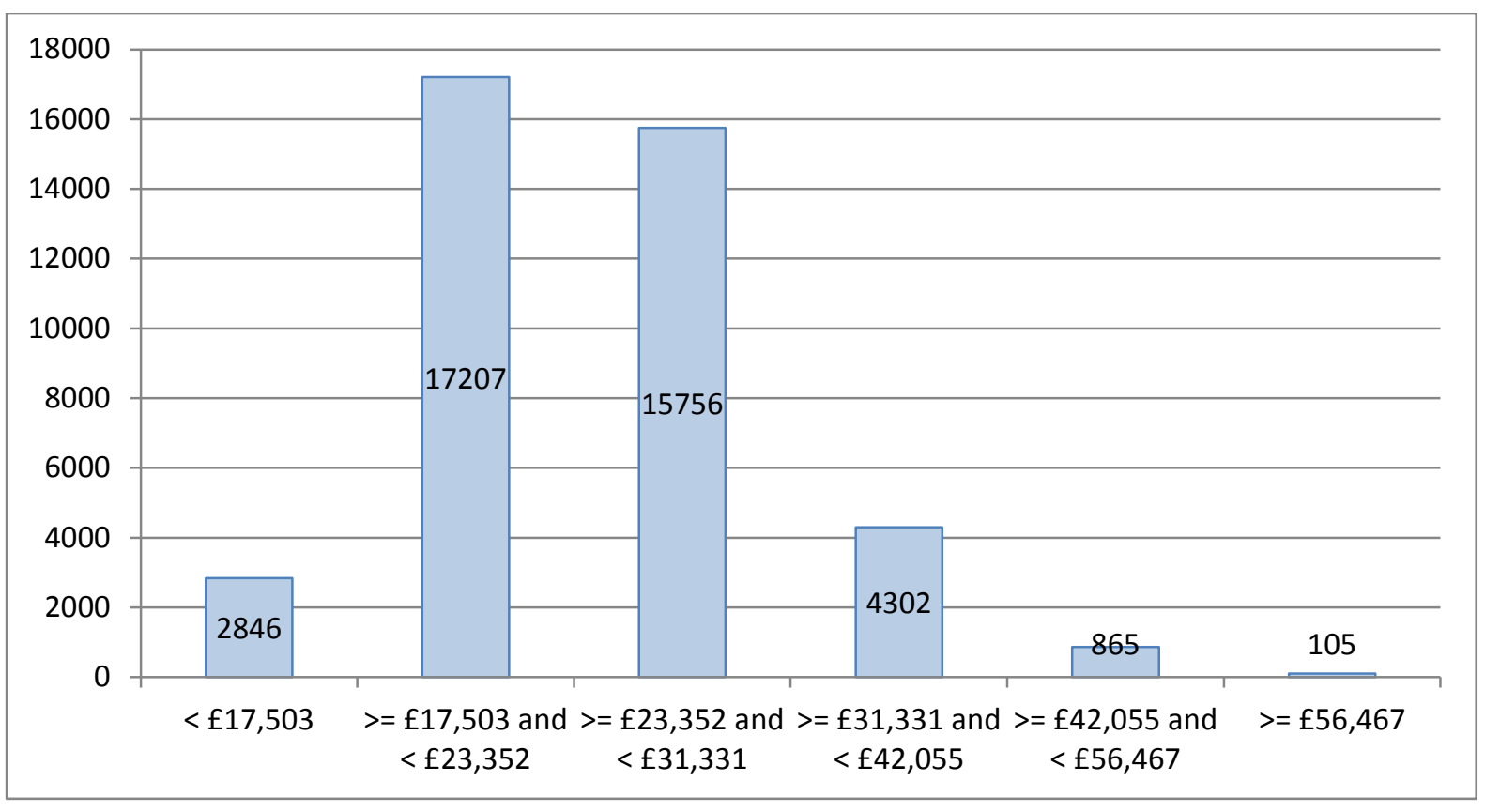

The mode point for staff in the managerial, professional and technical staff classifications was in the range of $£ 31,331-£ 42,055$. The mode point for secretarial staff was in the $£ 17,503-£ 23,352$. For staff on academic contracts the mode point was in the $£ 42,055-£ 56,467$ range. So administrative staff tend to be paid less than academic staff.

Details on age ranges are set out in Figure 5-8.

Figure 5: Age range of managers, directors and senior officials 2012/13

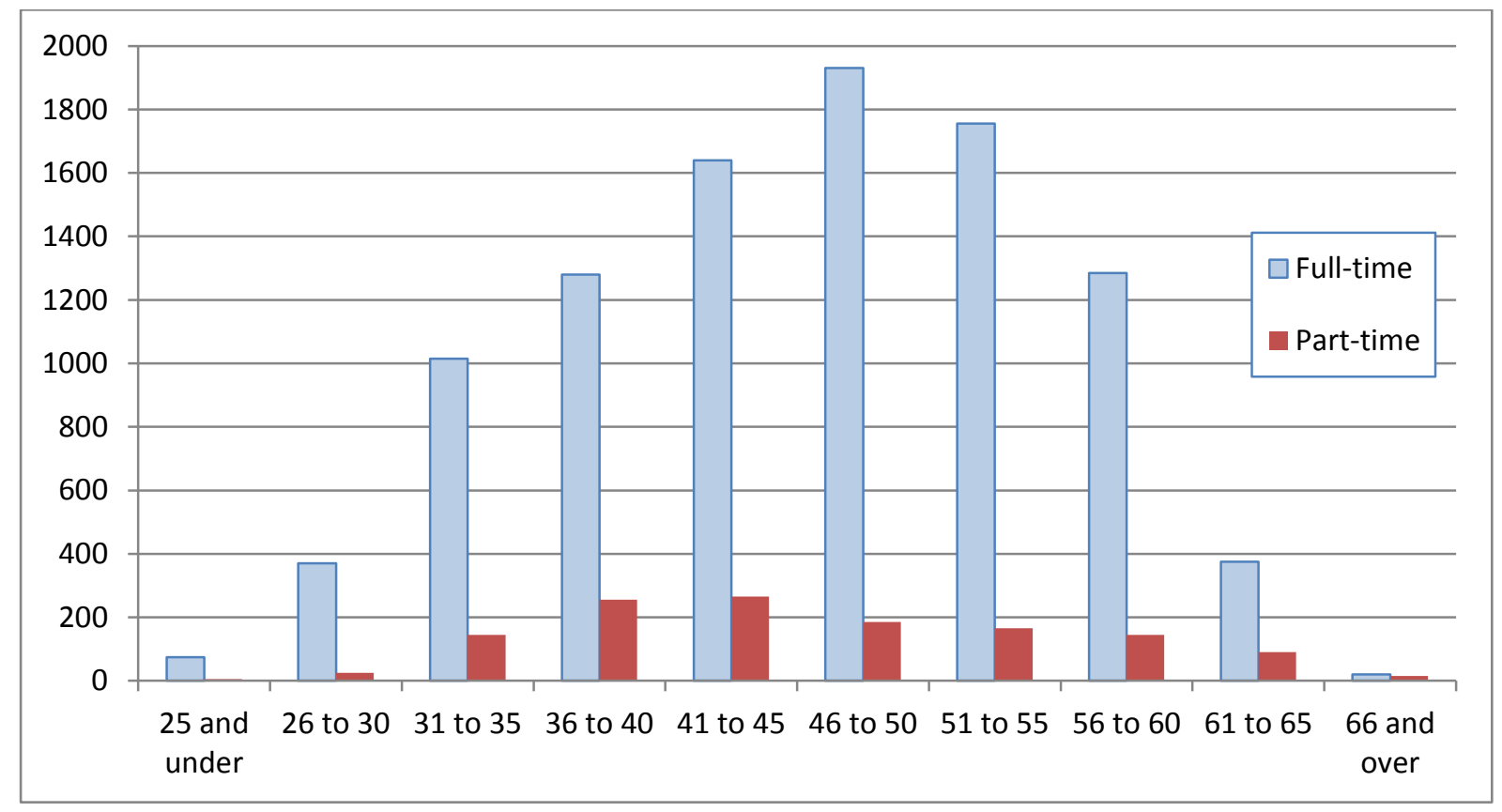

Figure 6: Age range of professional occupations 2012/13 


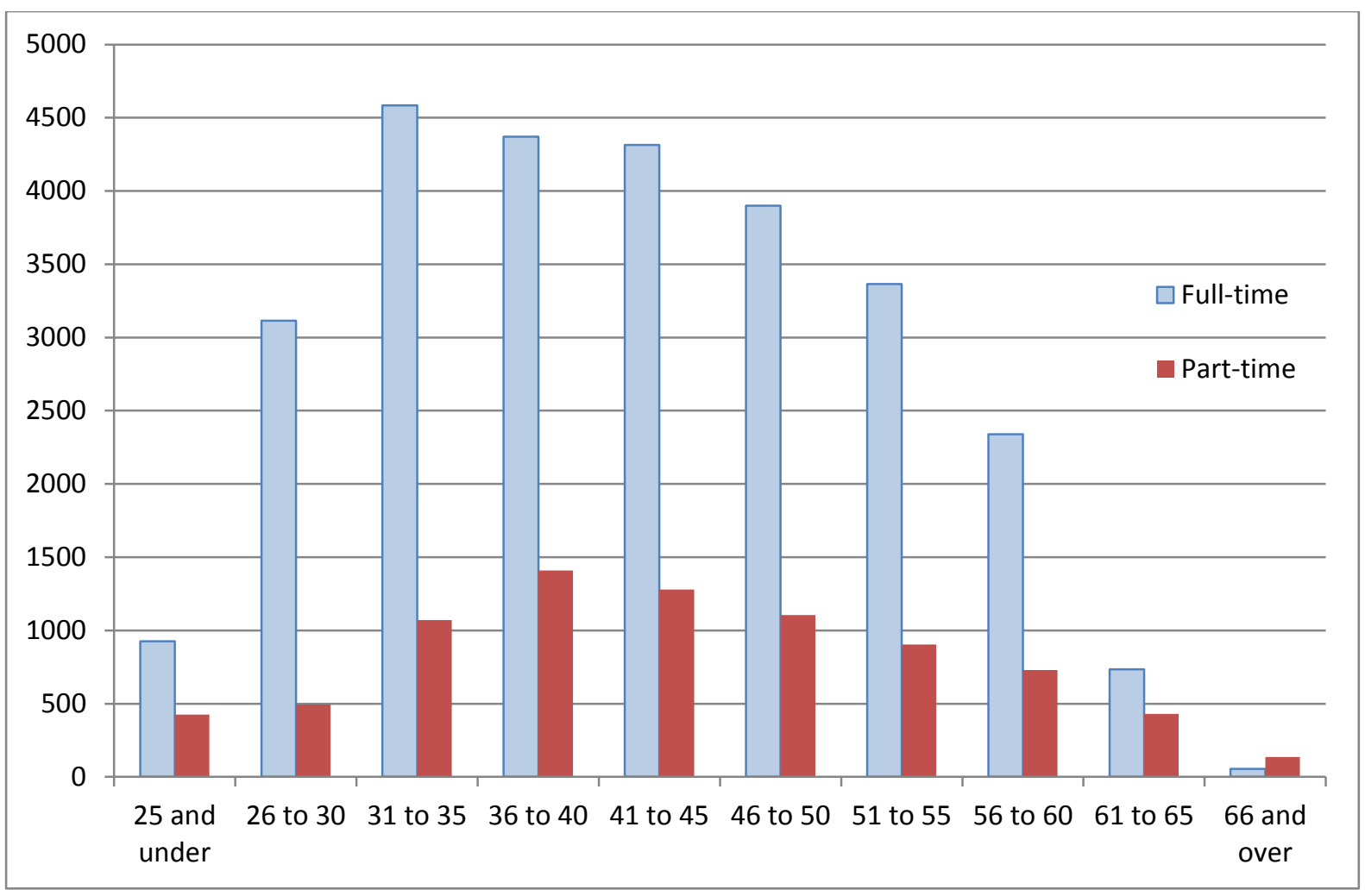

Figure 7: Age range of associate professional and technical occupations 2012/13

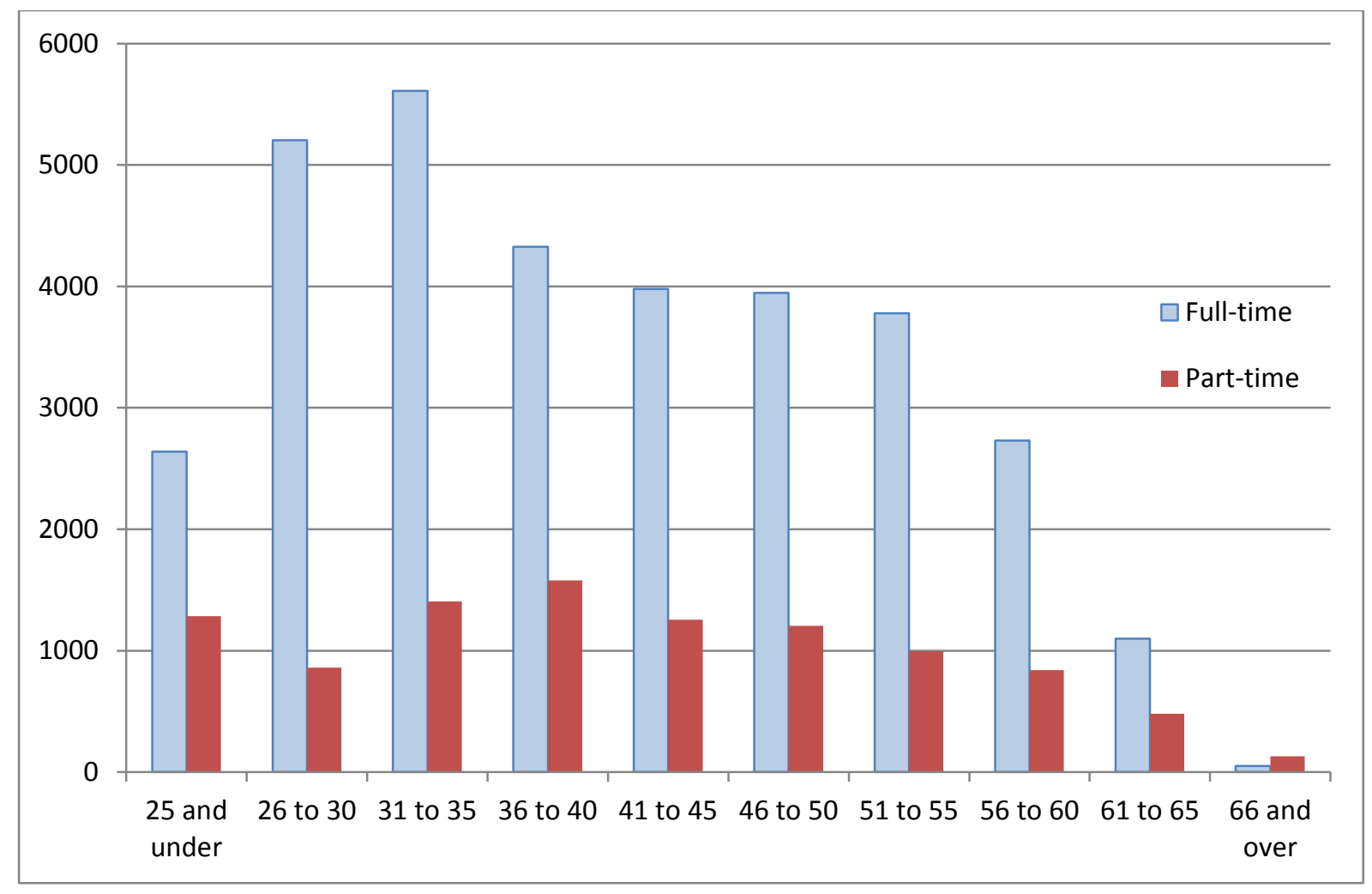

Figure 8: Age range of administrative and secretarial occupations 2012/13 


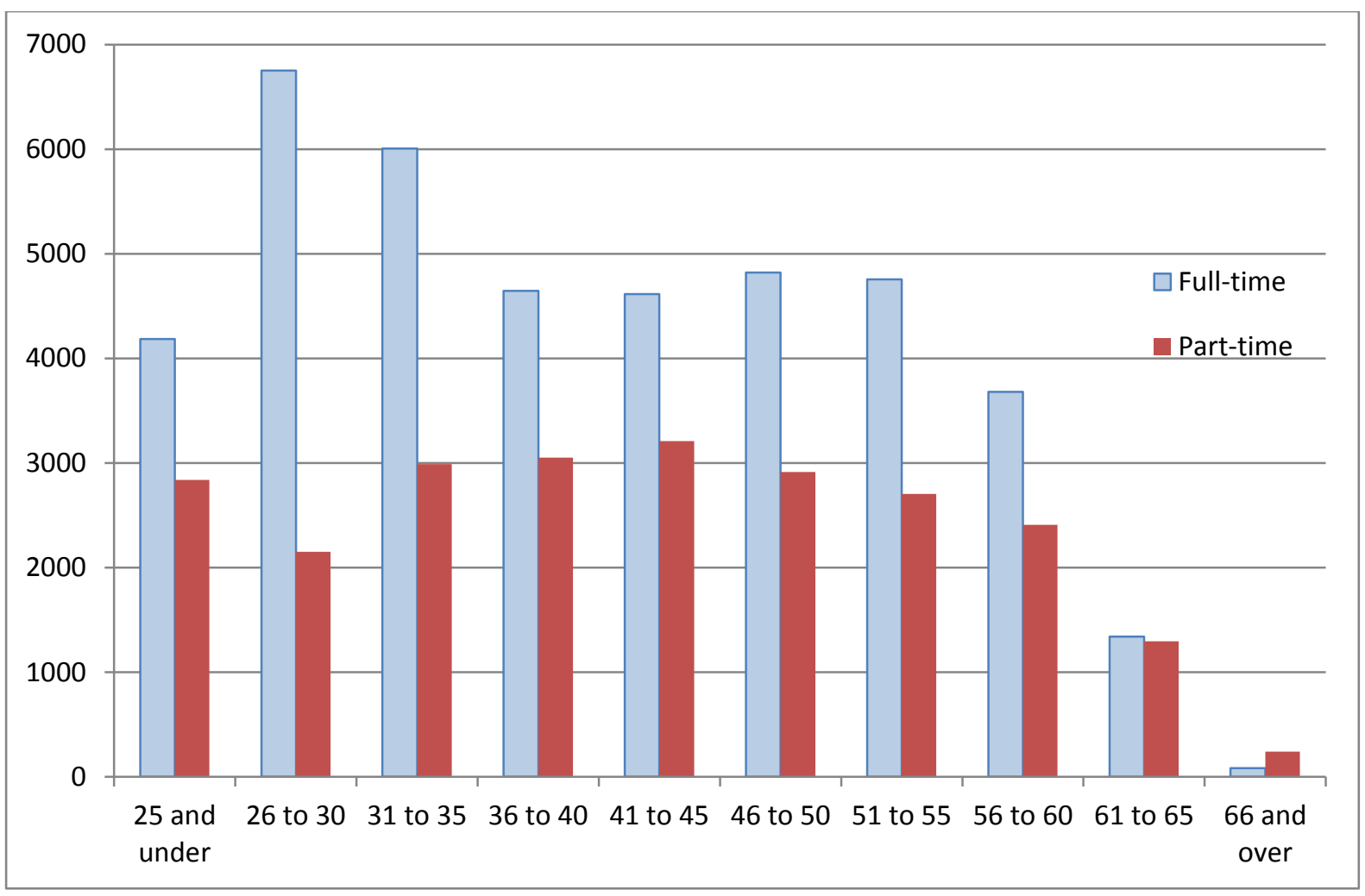

There are some obvious points. Managers, directors and senior officials tend to be older but the profile for the other classifications is more evenly distributed with notable peaks for clerical staff in their twenties and early thirties.

So where do administrators work in universities? This information is provided by the HESA cost centre code and is set out on Table 2.

Table 2: the location of University Administrators 2012/13

\begin{tabular}{|l|rrrrrr|}
\cline { 2 - 7 } & $\begin{array}{c}\text { Managers, } \\
\text { directors } \\
\text { and senior } \\
\text { officials }\end{array}$ & $\begin{array}{c}\text { Professional } \\
\text { Occupations }\end{array}$ & $\begin{array}{c}\text { Associate } \\
\text { professional } \\
\text { and technical } \\
\text { occupations }\end{array}$ & $\begin{array}{c}\text { Administrative } \\
\text { and secretarial } \\
\text { occupations }\end{array}$ & $\begin{array}{c}\text { Total } \\
\text { Growth } \\
\text { since } \\
2004 / 05\end{array}$ \\
\hline Academic Cost Centre & 2,220 & 13,940 & 18,305 & 24,935 & 59,400 & $-1 \%$ \\
Academic Services & 1,650 & 9,660 & 7,240 & 11,870 & 30,425 & $8 \%$ \\
Central Administration \& & 4,620 & 9,530 & 11,380 & 20,635 & 46,165 & $21 \%$ \\
services & 1,010 & 1,330 & 4,795 & 4,130 & 11,260 & $64 \%$ \\
Staff \& Student Facilities & 915 & 1,060 & 920 & 1,875 & 4,770 & $24 \%$ \\
Premises & 635 & 160 & 770 & 1,240 & 2,805 & $-20 \%$ \\
Residences \& catering & 11,050 & 35,680 & 43,410 & 64,685 & 154,830 & $10 \%$ \\
TOTAL & & & &
\end{tabular}

This is an important table because it challenges some lazy assumptions about where administrative staff work. More work in academic departments or schools than in the central administration and services as defined by HESA. Another $19.6 \%$ work in libraries, IT services, language centres or similar academic services. However, managers, directors and senior officials are more likely to work in the central services than academic departments or schools. So one issue for the way universities work is to note that most senior staff are located in a central set of services and most support in departments and schools will be less highly graded. 
It is also worth considering changes over time. HESA has published more detailed information on staff since 2004/05 (although there was a reclassification in 2012/13 which means the comparisons are not a perfect fit). In the period 2004/05 to 2012/13 managerial, professional and technical staff grew by $21 \%$ and clerical decreased by $2 \%$. There have also been different rates of growth with staff and student facilities (sports, welfare, careers and the like) growing at by far the fastest rate (64\%). This may well reflect the growing attention to the 'student experience' arising in part from higher fees in much of UK HE.

\section{Conclusion}

It is possible to suggest a working hypothesis for changes to administrators from these data. Technological changes have reduced the need for paper-intensive roles with systems in place to manage larger student numbers. Clerical staff numbers have actually declined but there is a need for more 'managers' to manage more complex systems. Clerical staff tend to be younger and with the single spine more progression opportunities have become available. So one potential explanation for the decline in clerical numbers is a move from clerical to the managerial, professional and technical staff classifications.

So what does a 'typical' administrator look like? Well there is no such thing but to generalise she is full-time, white, in her thirties and paid around $£ 30,000$. She will be working in a department where most staff are men.

\section{John Hogan}

References

Allen, D. and Newcomb, E. (1999) 'University management and administration: a profession for the $21^{\text {st }}$ century', perspectives: policy and practice in higher education Vol. 3, No. 2, pp.38-42

Angus, W. S. (1973) University Administrative Staff (Royal Institute of Public Administration, London)

Association of University Administrators (AUA) AUA website accessed 18 April 2014 http://www.aua.ac.uk/About.aspx

Dearing Report (1997) Higher Education in the Learning Society (Her Majesty's Stationery Office, London) Deem, R and Brehony, K.J. (2005) 'Management as ideology: the case of 'new managerialism' in higher education' Oxford Review of Education vol. 31, no. 2, pp. 217-235

HEFCE, (2012) Staff employed at HEFCE-funded HEls: Trends and profiles 1995-96 to 2010 -11 (HEFCE, July 2012/14, Bristol)

The Higher Education Statistics Agency (HESA) (2014). Staff at Higher Education Institutions in the United Kingdom 2012/13

HESA website accessed 17 April 2014

http://www.hesa.ac.uk/index.php?option=com content\&task=view\&id=3106\&ltemid=161

Jones, E. W. (1986) 'To plant our own trees' pp. 35-65 in Bosworth, S. (ed.) Beyond the Limelight (CUA, University of Reading, Reading)

Lauwerys, J. (2002) 'The future of the profession of university administration and management,' perspectives: policy and practice in higher education Vol. 4, No. 6, pp. 93-97

Lockwood, G. (1986) 'Role of University Administrators: Second Thoughts' pp. 81-87 in Bosworth, S. (ed.)

Beyond the Limelight (CUA, University of Reading, Reading)

Nature (1909) vol. 82, November pp. 3-4 A review of University Administration by C. W. Eliot University of Newcastle upon Tyne (1999) Calendar 1999-2000 volume 3 Staff List and Related Information (University of Newcastle upon Tyne, Newcastle upon Tyne) Whitchurch, C. (2009) 'Progressing professional careers in UK higher education' perspectives: policy and practice in higher education, Vol. 13, No. 1, pp. 2-9

Whitchurch, C. (2013) Reconstructing Identities in Higher Education: The Rise of 'Third Space' Professionals (Society for Research into Higher Education, Routledge) 